\title{
Volume contraction in the process of combustion of various fuels in combustion engines
}

\begin{abstract}
The paper discusses the issues related to the change of volume of the reagents during the process of combustion. The formulas that were necessary to make the calculations were derived for liquid and gaseous fuels. Based on the formulas, theoretical calculations of the change of the kilo-mole number for various fuels depending on the mixture composition were performed. The results of the calculations were presented in the tables. Further, the influence of volume contraction on the parameters of the combustion process was analyzed. In the conclusions, a comparison of the influence of the previously described phenomena on the individual fuels was performed in relation to their chemical composition and the composition of the mixture.
\end{abstract}

Keywords: internal combustion engine, combustion, contraction, engine fuels

\section{Kontrakcja w procesie spalania różnych paliw w silniku spalinowym}

W artykule poruszono zagadnienia związane ze zjawiskiem zmiany objętości reagentów podczas procesu spalania. Wyprowadzono konieczne do obliczeń wzory dla paliw ciektych i gazowych, na podstawie których przeprowadzono teoretyczne obliczenia zmiany liczby kilomoli dla różnych paliw w zależności o składu mieszanki palnej. Wyniki obliczeń zostały przedstawione w tabelach. Następnie przeanalizowano wptyw zjawiska kontrakcji na parametry procesu spalania. We wnioskach dokonano porównania wpływu opisanych wcześniej zjawisk na poszczególne paliwa w zależności od ich sktadu chemicznego oraz sktadu mieszanki palnej.

Słowa kluczowe: silnik spalinowy, spalanie, kontrakcja, paliwa silnikowe

\section{Introduction}

Thermodynamics of combustion processes is a very extensive field of knowledge. One of the issues it covers is volume contraction - a change in the volume of the reagents during combustion. We distinguish chemical and physical contraction The sum of the two constitutes total contraction. The chemical contraction is a change in the kilo-mole number of the gaseous products against the gaseous substrates. Physical contraction results from the reduction of the temperature of the exhaust gases until water vapor contained in the combustion products is condensed. The parameters that characterize the process of fuel combustion in an engine confine the contraction phenomenon to the chemical one.

Chemical reactions of combustion are accompanied by energy effects (release of a certain amount of heat) whose quality is defined by the resultant temperature. Temperature has a vital influence on the velocity of the chemical reaction.

Analyzing the course of the combustion process on an indicator tracing of an engine (Fig. 1) we can determine the crankshaft angle at which the change of the kilo-mole number of the reagents is initiated. Point 2 corresponds to this moment at which a parting of the compression line and the combustion line is visible [5].

\section{The calculation of the kilo-mole number of the reagents}

Since there is a variety of fuels used for the powering of combustion engines, the analysis of the combustion process

\section{Wstęp}

Termodynamika procesów spalania stanowi bardzo obszerna dziedzine wiedzy. Jednym z zagadnień, o jakim traktuje jest zjawisko kontrakcji, a więc zmiany objętości reagentów podczas spalania. Rozróżnia się kontrakcję chemiczną i fizyczną, których suma stanowi kontrakcję całkowitą. Kontrakcja chemiczna wynika ze zmiany liczby kilomoli produktów gazowych w stosunku do substratów gazowych. Natomiast kontrakcja fizyczna zachodzi na skutek zmniejszenia temperatury spalin, aż do wykroplenia pary wodnej zawartej w produktach spalania. Parametry charakteryzujące proces spalania paliwa w silnikach spalinowych powodują, iż w komorze spalania może zachodzić jedynie kontrakcja chemiczna.

Reakcjom chemicznym spalania towarzyszy efekt energetyczny w postaci wywiązywania się określonej ilości ciepła, o jakości którego decyduje temperatura. Temperatura ma zasadniczy wpływ na szybkość zachodzenia reakcji.

Rozpatrując przebieg procesu spalania na wykresie indykatorowym silnika (rys. 1) można wyznaczyć kąt obrotu wału korbowego, kiedy rozpoczyna się zjawisko zmiany liczby kilomoli reagentów. Odpowiada mu punkt 2, w którym następuje rozdzielenia linii sprężania od linii spalania [5].

\section{Obliczenia zmiany liczby kilomoli reagentów}

Ponieważ do zasilania silników spalinowych stosuje się różne paliwa, analiza procesu spalania oraz zjawiska kontrakcji zostały przeprowadzone zarówno dla paliw ciekłych jak i gazowych $[1,2,3,4,5,6]$. 
and volume contraction have been performed for both liquid and gaseous fuels [1-6].

The stoichiometric equation of the combustion of the liquid fuel composed of carbon, hydrogen and oxygen, assuming that the combustion is full and complete, can have the following general notation:

$$
\mathrm{C}_{\mathrm{m}} \mathrm{H}_{\mathrm{n}} \mathrm{O}_{\mathrm{k}}+(\mathrm{m}+(\mathrm{n} / 4)-(\mathrm{k} / 2)) \cdot \mathrm{O}_{2} \rightarrow \mathrm{m} \cdot \mathrm{CO}_{2}+\mathrm{n} / 2 \cdot \mathrm{H}_{2} \mathrm{O}
$$

For hydrocarbon gaseous fuels under the conditions of full and complete combustion the stoichiometric equation takes a general form:

$$
\mathrm{C}_{\mathrm{m}} \mathrm{H}_{\mathrm{n}}+(\mathrm{m}+(\mathrm{n} / 4)) \cdot \mathrm{O}_{2} \rightarrow \mathrm{m} \cdot \mathrm{CO}_{2}+\mathrm{n} / 2 \cdot \mathrm{H}_{2} \mathrm{O}
$$

In order to determine the change of the volume of the reagents during the combustion we need to define the substrates and products of the reaction using equations.

The number of kmoles o the combustible mixture when the engine is fueled with a liquid fuel:

$$
\mathrm{M}_{\mathrm{c}}=\lambda \cdot \mathrm{L}_{\mathrm{t}}[\mathrm{kmol} / \mathrm{kg} \text { of fuel }]
$$

The equation has a simplification of not including the share of fuel in the mixture, as it is negligibly small compared to air.

The number of kmoles of the combustible mixture when the engine is fueled with gaseous fuel:

$$
\mathrm{M}_{\mathrm{g}}=1+\lambda \cdot \mathrm{L}_{\mathrm{t}}[\mathrm{kmol} / \mathrm{kmol} \text { of fuel }]
$$

The number of kmoles of humid exhaust gas during a full and complete combustion of liquid fuel:

$$
\mathrm{M}_{\mathrm{spc}}=\mathrm{H} / 4+\mathrm{O} / 32+\lambda \cdot \mathrm{L}_{\mathrm{t}}[\mathrm{kmol} / \mathrm{kg} \text { of fuel }]
$$

The number of kmoles of humid exhaust gas during a full and complete combustion of gaseous fuel:

$$
\mathrm{M}_{\mathrm{sp} \mathrm{g}}=\mathrm{n} / 4 \cdot \mathrm{C}_{\mathrm{m}} \mathrm{H}_{\mathrm{n}}+\lambda \cdot \mathrm{L}_{\mathrm{t}}[\mathrm{kmol} / \mathrm{kmol} \text { of fuel }]
$$

In general, the change in the number of kmoles can be written:

$$
\Delta \mathrm{M}=\mathrm{M}_{\mathrm{sp}}-\mathrm{M}
$$

hence, for the combustion of liquid fuel it takes a form:

$$
\Delta \mathrm{M}_{\mathrm{c}}=\mathrm{H} / 4+\mathrm{O} / 32[\mathrm{kmol} / \mathrm{kg} \text { of fuel }]
$$

and for the combustion of gaseous fuel:

$$
\Delta \mathrm{M}_{\mathrm{g}}=\mathrm{n} / 4 \cdot \mathrm{C}_{\mathrm{m}} \mathrm{H}_{\mathrm{n}}-1[\mathrm{kmol} / \mathrm{kmol} \text { of fuel }]
$$

The consequence of the analysis of combustion as a full and complete process (theoretically for stoichiometric and lean mixtures) is that the excess air coefficient does not influence the calculations of the change in the kmole
Równanie stechiometryczne spalania paliwa ciekłego, w którego skład wchodzi węgiel, wodór i tlen, przy założeniu, iż spalanie jest zupełne i całkowite można zapisać w ogólnej postaci za pomocą równania (1).

Natomiast dla węglowodorowych paliw gazowych przy założeniu spalania zupełnego i całkowitego równanie stechiometryczne przyjmuje ogólną postać - równanie (2).

W celu określenia zmiany objętości reagentów podczas spalania należy za pomocą równań zdefiniować

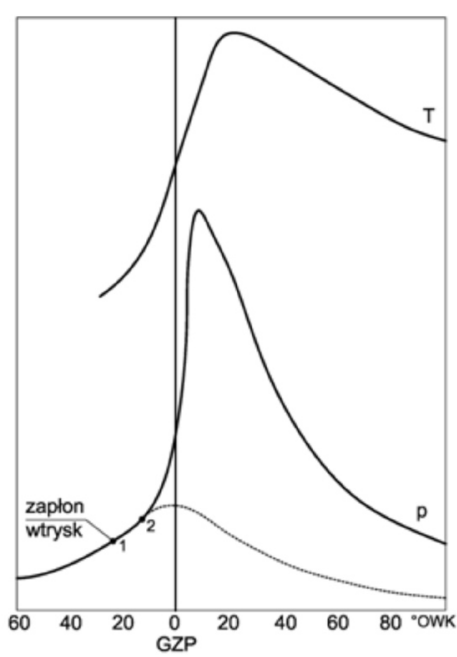

Fig. 1. The course of the pressure and temperature change in the combustion chamber as a function of crankshaft angle

Rys. 1. Przebieg zmian ciśnienia i temperatury $w$ komorze spalania w funkcji kąta obrotu wału korbowego cjach substraty i produkty spalania.

Liczba kilomoli mieszanki palnej przy zasilaniu silnika paliwem ciekłym dana jest w postaci równania (3).

We wzorze (3) poczyniono uroszczenie nie uwzględniając udziału paliwa w mieszance, gdyż jest on pomijalnie mały w porównaniu do powietrza.

Liczba kilomoli mieszanki palnej przy zasilaniu silnika paliwem gazowym dana jest w postaci równania (4).

Liczba kilomoli spalin wilgotnych przy spalaniu zupełnym i całkowitym paliwa ciekłego - równanie (5).

Liczbę kilomoli spalin wilgotnych przy spalaniu zupełnym i całkowitym paliwa gazowego określa równanie (6).

Ogólnie zmianę liczby kilomoli można zapisać w postaci równania (7).

W związku, z czym dla procesu spalania paliwa ciekłego przyjmuje postać (8)

A dla procesu spalania paliwa gazowego postać (9).

Rozpatrywanie spalania, jako procesu zupełnego i całkowitego, a więc teoretycznie dla mieszanek stechiometrycznej i ubogich powoduje, iż współczynnik nadmiaru powietrza nie wpływa na obliczenia zmiany liczby kilomoli, a jedynie udziały składników palnych w paliwie. Jednak w przypadku spalania niezupełnego skład mieszanki również oddziałuje na efekt zjawiska kontrakcji chemicznej. W silnikach spalinowych spalanie niezupełnie nie jest tylko wynikiem niedomiaru powietrza $\mathrm{w}$ mieszance palnej $(\lambda<1)$, ale także efektem niedoskonałego wymieszania paliwa z powietrzem oraz zbyt krótkiego czasu na przeprowadzenie reakcji chemicznych.

Proces spalania niezupełnego paliwa ciekłego można przedstawić za pomocą równania (10).

Proces spalania niezupełnego paliwa gazowego przedstawiono za pomocą równania (11). 
number but only the shares of the combustible components in the fuel. However, in the case of incomplete combustion the fuel composition also influences the effect of chemical contraction. In combustion engines incomplete combustion is not exclusively a result of air deficiency in the combustible mixture $(\lambda<1)$ but also the effect of an imperfect mixing of the fuel with air and an insufficient time for the chemical reaction.

The process of incomplete combustion of liquid fuel:

$$
\Delta \mathrm{M}_{\mathrm{c}}=\mathrm{C} / 12+\mathrm{H} / 2-0.21 \cdot \lambda \cdot \mathrm{L}_{\mathrm{t}}[\mathrm{kmol} / \mathrm{kg} \text { of fuel }]
$$

The process of incomplete combustion of gaseous fuel:

$$
\begin{gathered}
\Delta \mathrm{M}_{\mathrm{g}}=\mathrm{m} \cdot \mathrm{C}_{\mathrm{m}} \mathrm{H}_{\mathrm{n}}+\mathrm{n} / 2 \cdot \mathrm{C}_{\mathrm{m}} \mathrm{H}_{\mathrm{n}}-0.21 \cdot \lambda \cdot \mathrm{L}_{\mathrm{t}}-1 \\
{[\mathrm{kmol} / \mathrm{kmol} \text { of fuel }]}
\end{gathered}
$$

In order to enable a comparison of the change of the volume of the reagents for liquid and gaseous fuels a relative coefficient of contraction is applied that constitutes the quotient of the kmoles of the combustion products and substrates.

$$
\beta_{\mathrm{t}}=\mathrm{M}_{\mathrm{sp}} / \mathrm{M}
$$

Theoretical coefficient of contraction during a complete combustion of liquid fuel:

$$
\beta_{\mathrm{tc}}=1+(\mathrm{H} / 4+\mathrm{O} / 32) /\left(\lambda \cdot \mathrm{L}_{\mathrm{t}}\right)
$$

Theoretical coefficient of contraction during a complete combustion of gaseous fuel:

$$
\beta_{\mathrm{tg}}=\left(\mathrm{n} / 4 \cdot \mathrm{C}_{\mathrm{m}} \mathrm{H}_{\mathrm{n}}+\lambda \cdot \mathrm{L}_{\mathrm{t}}\right) /\left(1+\lambda \cdot \mathrm{L}_{\mathrm{t}}\right)
$$

Theoretical coefficient of contraction during an incomplete combustion of liquid fuel:

$$
\beta_{\mathrm{tc}}=\left(\mathrm{C} / 12+\mathrm{H} / 2+0.79 \cdot \lambda \cdot \mathrm{L}_{\mathrm{t}}\right) /\left(\lambda \cdot \mathrm{L}_{\mathrm{t}}\right)
$$

Theoretical coefficient of contraction during an incomplete combustion of gaseous fuel:

$$
\beta_{\mathrm{tg}}=\left(\mathrm{m} \cdot \mathrm{C}_{\mathrm{m}} \mathrm{H}_{\mathrm{n}}+\mathrm{n} / 4 \cdot \mathrm{C}_{\mathrm{m}} \mathrm{H}_{\mathrm{n}}+0.79 \cdot \lambda \cdot \mathrm{L}_{\mathrm{t}}\right) /\left(1+\lambda \cdot \mathrm{L}_{\mathrm{t}}\right)
$$

Under actual conditions in the combustion chamber a part of the exhaust gas remains after the previous work cycle, which should be allowed for in the formula for the coefficient of contraction. In modern engines, exhaust gas recirculation is frequently applied that can also be allowed for in the calculations by the charge contamination coefficient $(\gamma)$.

$$
\beta=\left(M_{\text {sp }}+M_{r}\right) /\left(M+M_{r}\right)=\left(\beta_{t}+\gamma\right) /(1+\gamma)
$$

Based on the derived formulas the authors performed calculations of theoretical change of number of the reagents taking part in the combustion process $(\Delta \mathrm{M})$ and then theoretical contraction coefficient $\left(\beta_{\mathrm{t}}\right)$ and contraction coefficient $(\beta)$
Aby możliwe było porównanie zjawiska zmiany objętości reagentów dla paliw ciekłych i gazowych stosuje się względny współczynnik kontrakcji stanowiący iloraz liczby kilomoli produktów spalania i substratów - równanie (12).

Teoretyczny współczynnik kontrakcji przy spalaniu zupełnym paliwa ciekłego wyraża równanie (13).

Teoretyczny współczynnik kontrakcji przy spalaniu zupełnym paliwa gazowego przedstawiono za pomocą równania (14).

Teoretyczny współczynnik kontrakcji przy spalaniu niezupełnym paliwa ciekłego wyrażą równanie (15).

Teoretyczny współczynnik kontrakcji przy spalaniu niezupełnym paliwa gazowego określa równanie (16).

W rzeczywistych warunkach w komorze spalania pozostaje reszta spalin, która nie zdąży opuścić cylindra po poprzednim cyklu pracy, co należy uwzględnić we wzorze na współczynnik kontrakcji. Obecnie również często stosuje się recyrkulację spalin, którą również można uwzględnić w obliczeniach za pomocą współczynnika zanieczyszczenia ładunku $(\gamma)$ określonego w równaniu (17).

$\mathrm{Na}$ podstawie wyprowadzonych wzorów przeprowadzono obliczenia teoretyczne zmiany liczby reagentów biorących udział $\mathrm{w}$ procesie spalania $(\Delta \mathrm{M})$, a następnie teoretycznego współczynnika kontrakcji $\left(\beta_{\mathrm{t}}\right)$ oraz współczynnika kontrakcji $(\beta)$ uwzględniającego współczynnik zanieczyszczenia ładunku, przy czym przyjęto jego stałą wartość $\gamma=0,05$. Obliczenia zostały wykonane dla paliw ciekłych i gazowych.

Tabela 1 zawiera wyniki dla konwencjonalnych paliw ciekłych, a więc benzyny i oleju napędowego oraz dla alternatywnych paliw ciekłych w postaci alkoholu metylowego i etylowego, mieszaniny benzyny z alkoholem etylowym (E85 i E5), a także mieszaniny oleju napędowego z paliwami pochodzenia roślinnego (B5, B30) i czystego paliwa roślinnego B100 przy założeniu, że mieszanka jest stechiometryczna.

Table. 1. Mass shares of the fuel components, change of kmole number and the coefficients of contraction for the liquid fuels

Tabela. 1. Udziały masowe składników paliw, zmiana liczby kilomoli oraz wspótczynniki kontrakcji dla paliw ciekłych

\begin{tabular}{|l|c|c|c|c|c|c|}
\hline $\begin{array}{l}\text { Liquid fuels/ } \\
\text { paliwa ciekte }\end{array}$ & $\begin{array}{c}\text { Share C/ } \\
\text { udziat C }\end{array}$ & $\begin{array}{l}\text { Share } \mathrm{H} / \\
\text { udziat H }\end{array}$ & $\begin{array}{c}\text { Share O/ } \\
\text { udziat O }\end{array}$ & $\begin{array}{c}\Delta \mathrm{M} \\
{[\mathrm{kmol} /} \\
\mathrm{kg} \mathrm{pal}]\end{array}$ & $\begin{array}{l}\beta_{\mathrm{t}} \text { for } \\
\lambda=1\end{array}$ & $\begin{array}{c}\beta \text { for } \\
\lambda=1\end{array}$ \\
\hline $\begin{array}{l}\text { Gasoline/ } \\
\text { benzyna }\end{array}$ & 0.85 & 0.15 & 0 & 0.0375 & 1.0193 & 1.0184 \\
\hline $\begin{array}{l}\text { Diesel fuel/ } \\
\text { olej } \\
\text { napędowy }\end{array}$ & 0.86 & 0.14 & 0 & 0.035 & 1.0178 & 1.0169 \\
\hline $\begin{array}{l}\text { Methanol/ } \\
\text { alkohol } \\
\text { metylowy }\end{array}$ & 0.375 & 0.125 & 0.5 & 0.0469 & 1.0105 & 1.0100 \\
\hline $\begin{array}{l}\text { Ethanol/alko- } \\
\text { hol etylowy }\end{array}$ & 0.522 & 0.13 & 0.348 & 0.0435 & 1.0135 & 1.0129 \\
\hline E85 & 0.571 & 0.133 & 0.296 & 0.0426 & 1.0145 & 1.0138 \\
\hline E5 & 0.834 & 0.149 & 0.017 & 0.0378 & 1.0191 & 1.0182 \\
\hline B5 & 0.856 & 0.139 & 0.005 & 0.0349 & 1.0176 & 1.0168 \\
\hline B30 & 0.833 & 0.134 & 0.032 & 0.0346 & 1.0168 & 1.0160 \\
\hline B100 & 0.770 & 0.122 & 0.108 & 0.0338 & 1.0147 & 1.0140 \\
\hline
\end{tabular}


allowing for the coefficient of charge contamination (whose value was assumed as constant of $\gamma=0.05$ ). The calculations were made for liquid and gaseous fuels.

Table 1 contains the results for conventional liquid fuels i.e. gasoline and diesel fuel and alternative liquid fuels such as methanol and ethanol, a mixture of gasoline and ethanol (E85 and E5) as well as a mixture of diesel fuel with vegetable fuels (B5, B30) and pure vegetable fuel B100 assuming a stoichiometric mixture.

Table 2 presents the results for gaseous fuels adequate to those contained in Table 1 (a mixture of propane and butane, methane and hydrogen were included).

The results of the calculations of the theoretical coefficient of contraction $\left(\beta_{t}\right)$ at different mixture composition have been shown in Table 3 and for gaseous fuels in Table 4 .

Table. 3. Theoretical coefficient of contraction depending on the excess air coefficient for liquid fuels

Tabela. 3. Teoretyczny wspótczynnik kontrakcji w zależności od wspótczynnika nadmiaru powietrza dla paliw ciektych

\begin{tabular}{|l|c|c|c|c|c|}
\hline $\begin{array}{l}\text { Liquid fuels/pali- } \\
\text { wa ciekłe }\end{array}$ & $\begin{array}{c}\beta_{\mathrm{t}} \text { for } \\
\lambda=0.8\end{array}$ & $\begin{array}{c}\beta_{\mathrm{t}} \text { for } \\
\lambda=1\end{array}$ & $\begin{array}{c}\beta_{\mathrm{t}} \text { for } \\
\lambda=1.2\end{array}$ & $\begin{array}{c}\beta_{\mathrm{t}} \text { for } \\
\lambda=1.4\end{array}$ & $\begin{array}{c}\beta_{\mathrm{t}} \text { for } \\
\lambda=1.6\end{array}$ \\
\hline Gasoline/benzyna & 0.3043 & 1.0193 & 1.0161 & 1.0138 & 1.0121 \\
\hline $\begin{array}{l}\text { Diesel fuel/olej } \\
\text { napędowy }\end{array}$ & 0.2938 & 1.0178 & 1.0148 & 1.0127 & 1.0111 \\
\hline $\begin{array}{l}\text { Methanol/alkohol } \\
\text { metylowy }\end{array}$ & 0.0655 & 1.0105 & 1.0087 & 1.0075 & 1.0065 \\
\hline $\begin{array}{l}\text { Ethanol/alkohol } \\
\text { etylowy }\end{array}$ & 0.1183 & 1.0135 & 1.0112 & 1.0096 & 1.0084 \\
\hline E85 & 0.1408 & 1.0145 & 1.0121 & 1.0104 & 1.0091 \\
\hline E5 & 0.2929 & 1.0191 & 1.0159 & 1.0137 & 1.0119 \\
\hline B5 & 0.2896 & 1.0176 & 1.0147 & 1.0126 & 1.0110 \\
\hline B30 & 0.2695 & 1.0168 & 1.0140 & 1.0120 & 1.0105 \\
\hline B100 & 0.2169 & 1.0147 & 1.0122 & 1.0105 & 1.0092 \\
\hline
\end{tabular}

\section{The influence of volume contraction on the combustion process}

The process of combustion in a combustion engine lasts for several degrees of the crankshaft angle, during which the amount of oxidized fuel changes continuously, hence the coefficient of change of the kmole number. That is why, when analyzing the process of combustion we introduce a current coefficient of change of the kmole number that allows for the share of the burned fuel (x).

$$
\beta_{x}=M_{x} / M_{1}=1+(\beta-1) \cdot x=1+\left(\beta_{t}-1\right) /(1+\gamma) \cdot x
$$

Hence, treating the working medium as an ideal gas, thus using the equation of state of ideal gases to calculate the temperature of the working medium current coefficient of change of the kmole number is introduced in the formula.

$$
\mathrm{T}=(\mathrm{p} \cdot \mathrm{V}) /\left(\beta_{\mathrm{x}} \cdot \mathrm{M}_{1} \cdot \mathrm{R}\right)
$$

Assuming that the combustion process is an isochoric one the phenomenon of chemical contraction influences
Table. 2. Molar fractions of the fuel components, change in the kmole number and coefficients of contraction for gaseous fuels

Tabela. 2. Udziaty molowe składników paliw, zmiana liczby kilomoli oraz wspótczynniki kontrakcji dla paliw gazowych

\begin{tabular}{|l|c|c|c|c|c|}
\hline $\begin{array}{l}\text { Gaseous } \\
\text { fuels/paliwa } \\
\text { gazowe }\end{array}$ & $\begin{array}{l}\text { Share C/ } \\
\text { udział C }\end{array}$ & $\begin{array}{c}\text { Share H/ } \\
\text { udział H }\end{array}$ & $\begin{array}{c}\Delta \mathrm{M} \\
{[\mathrm{kmol} /} \\
\mathrm{kmol} \mathrm{pal}]\end{array}$ & $\begin{array}{l}\beta_{\mathrm{t}} \text { for } \\
\lambda=1\end{array}$ & $\begin{array}{c}\beta \text { for } \\
\lambda=1\end{array}$ \\
\hline $\begin{array}{l}\text { Propane- } \\
\text { butane/ } \\
\text { propan-butan } \\
(50 \% / 50 \%)\end{array}$ & 3.5 & 9 & 1.25 & 1.0440 & 1.0419 \\
\hline $\begin{array}{l}\text { Methane/ } \\
\text { metan }\end{array}$ & 1 & 4 & 0 & 1 & 1 \\
\hline $\begin{array}{l}\text { Hydrogen/ } \\
\text { wodór }\end{array}$ & 0 & 2 & -0.5 & 0.8521 & 0.8592 \\
\hline
\end{tabular}

Table. 4. Theoretical coefficient of contraction depending on the excess air coefficient for gaseous fuels

Tabela. 4. Teoretyczny współczynnik kontrakcji w zależności od wspótczynnika nadmiaru powietrza dla paliw gazowych

\begin{tabular}{|l|c|c|c|c|c|}
\hline $\begin{array}{l}\text { Gaseous fuels/ } \\
\text { paliwa gazowe }\end{array}$ & $\begin{array}{c}\beta_{\mathrm{t}} \text { for } \\
\lambda=0.8\end{array}$ & $\begin{array}{c}\beta_{\mathrm{t}} \text { for } \\
\lambda=1.0\end{array}$ & $\begin{array}{c}\beta_{\mathrm{t}} \text { for } \\
\lambda=1.2\end{array}$ & $\begin{array}{c}\beta_{\mathrm{t}} \text { for } \\
\lambda=1.4\end{array}$ & $\begin{array}{c}\beta_{\mathrm{t}} \text { for } \\
\lambda=1.6\end{array}$ \\
\hline $\begin{array}{l}\text { propane-butane/ } \\
\text { propan-butan } \\
(50 \% / 50 \%)\end{array}$ & 1.1048 & 1.0440 & 1.0369 & 1.0318 & 1.0279 \\
\hline Methane/metan & 1.0464 & 1.0 & 1.0 & 1.0 & 1.0 \\
\hline Hydrogen/wodór & 0.8623 & 0.8521 & 0.8704 & 0.8846 & 0.8960 \\
\hline
\end{tabular}

W tabeli 2 przedstawiono adekwatne do zawartych w tabeli 1 wyniki dla paliw gazowych, przy czym uwzględniono mieszaninę propanu $\mathrm{z}$ butanem, metan i wodór.

Wyniki obliczeń teoretycznego współczynnika kontrakcji $\left(\beta_{\mathrm{t}}\right)$ przy różnym składzie mieszanki palnej umieszczono dla paliw ciekłych $\mathrm{w}$ tabeli 3 , a dla paliw gazowych $\mathrm{w}$ tabeli 4 .

\section{Wpływ zjawiska kontrakcji na proces spalania}

Proces spalania w silniku spalinowym trwa kilkadziesiąt stopni obrotu wału korbowego, podczas którego ilość utlenionego paliwa ulega ciągłej zmianie, a zatem również współczynnik zmiany liczby kilomoli. Dlatego analizując szczegółowo proces spalania wprowadza się bieżący współczynnik zmiany liczby kilomoli, uwzględniający udział spalonego paliwa $(\mathrm{x})$ - równanie (18).

Stąd traktując czynnik roboczy jako gaz doskonały i w związku z tym wykorzystując równanie stanu gazów doskonałych do obliczenia temperatury czynnika, wprowadza się do wzoru bieżący współczynnik zmiany liczby kilomoli - (19).

Przy założeniu, iż proces spalania przebiega izochorycznie, zjawisko kontrakcji chemicznej ma wpływ na przyrost ciśnienia w komorze spalania. A mianowicie, jeżeli nie następuje zmiana liczby kilomoli $\mathrm{w}$ wyniku spalania $\left(\beta_{\mathrm{x}}=1\right)$ to przyrost ciśnienia jest proporcjonalny tylko do przyrostu temperatury w cylindrze. Natomiast w przypadku zmiany liczby kilomoli reagentów $\left(\beta_{\mathrm{x}}>1\right)$ przyrost ciśnienia jest proporcjonalny do przyrostu iloczynu temperatury i liczby kilomoli, co skutkuje większą wartością przyrostu ciśnienia - równanie (20). 
the pressure increment in the combustion chamber. If the change of the kmole number does not take place as a result of combustion $\left(\beta_{x}=1\right)$ the pressure increment is proportional only to the temperature increment in the cylinder. If the kmole number of the reagents changes $\left(\beta_{\mathrm{x}}>1\right)$ the pressure increment is proportional to the increment of the product of the temperature and the kmole number, which results in a greater value of the pressure increment.

$$
(\Delta \mathrm{p})_{\mathrm{v}}=\beta_{\mathrm{x}} \cdot \mathrm{M}_{1} \cdot \mathrm{R} / \mathrm{V} \cdot \Delta \mathrm{T}
$$

For example: assuming, for the stoichiometric mixture of gasoline and air, that the calculations are made for $1 \mathrm{kmole}$ of the working medium:

$$
\mathrm{M}_{1} / \mathrm{V}=1 / \Phi=1 / 22.4 \mathrm{kmol}\left(\mathrm{Nm}^{3}\right)
$$

and the change in the temperature is $\Delta \mathrm{T}=2000[\mathrm{~K}]$, then, not including the changes in the kmole number during the combustion $\left(\beta_{\mathrm{x}}=1\right)$ the theoretical value of the pressure change will be:

$$
(\Delta \mathrm{p})_{\mathrm{v}}=742.321 \mathrm{kPa} .
$$

If we include the change of the kmole number $\left(\beta_{\mathrm{x}}=1.0184\right)$ the theoretical value of the pressure change will be:

$$
(\Delta \mathrm{p})_{\mathrm{v}}=755.980 \mathrm{kPa}
$$

Analyzing the combustion process according to the principles of thermodynamics, taking into account the chemical reactions, we practically discuss isochoric-isothermal and isobaric-isothermal reactions [6]. That is why the thermal effect of the isochoric-isothermal reaction (according to the first law of thermodynamics) equals the increment of the internal energy of the reagents:

$$
\mathrm{Q}_{\mathrm{V}, \mathrm{T}}=\mathrm{U}_{\mathrm{sp}}-\mathrm{U}=\sum \mathrm{v} \cdot \overline{\mathrm{U}}
$$

Hence, the thermal effect of the isobaric-isothermal reaction equals the increment of the enthalpy of the reagents.

$$
\mathrm{Q}_{\mathrm{p}, \mathrm{T}}=\mathrm{U}_{\mathrm{sp}}-\mathrm{U}+\mathrm{p}\left(\mathrm{V}_{\mathrm{sp}}-\mathrm{V}\right)=\sum \mathrm{v} \cdot(\overline{\mathrm{U}}+\mathrm{p} \overline{\mathrm{V}})
$$

From the equations describing the thermal effect of the reaction it results that with an increase in the kmole number of the reagents $\left(\sum v>0\right)$ the thermal effect of the isobaric-isothermal reaction is greater than the thermal effect of the isochoric-isothermal reaction $\left(Q_{p, T}>Q_{V, T}\right)$. If the kmole number of the reagents does not change $\left(\sum \mathrm{v}=0\right)$ then the thermal effects of both reactions are equal $\left(Q_{p, T}=\right.$ $\left.=\mathrm{Q}_{\mathrm{V}, \mathrm{T}}\right)$ and when the kmole number is reduced $\left(\sum \mathrm{v}<0\right)$ the thermal effect of the isobaric-isothermal reaction is lesser than the thermal effect of the isochoric-isothermal reaction $\left(\mathrm{Q}_{\mathrm{p}, \mathrm{T}}<\mathrm{Q}_{\mathrm{V}, \mathrm{T}}\right)$.

In theoretical considerations of combustion engine cycles isochoric course of combustion is assumed in spark ignition
Przykładowo dla zasilania mieszanką stechiometryczną benzyny z powietrzem, przy założeniu, że obliczenia wykonywane są dla 1 kilomola czynnika roboczego, więc:

$$
\mathrm{M}_{1} / \mathrm{V}=1 / \Phi=1 / 22.4 \mathrm{kmol}\left(\mathrm{Nm}^{3}\right)
$$

A zmiana temperatury będzie równa $\Delta \mathrm{T}=2000 \mathrm{~K}$.

To nie uwzględniając zmiany liczby kilomoli podczas spalania $\left(\beta_{\mathrm{x}}=1\right)$, teoretyczna wartość zmiany ciśnienia wyniesie:

$$
(\Delta \mathrm{p})_{\mathrm{v}}=742,321 \mathrm{kPa}
$$

Natomiast, jeżeli uwzględni się zmianę liczby kilomoli $\left(\beta_{x}=1,0184\right)$ teoretyczna wartość zmiany ciśnienia wyniesie:

$$
(\Delta \mathrm{p})_{\mathrm{v}}=755,980 \mathrm{kPa}
$$

Analizując proces spalania według zasad termodynamiki z uwzględnieniem reakcji chemicznych rozpatruje się w zasadzie reakcje izochoryczno-izotermiczne i reakcje izobaryczno-izotermiczne [6]. Dlatego efekt cieplny reakcji izochoryczno-izotermicznej, zgodnie z pierwszą zasadą termodynamiki jest równy przyrostowi energii wewnętrznej reagentów, określony przez równanie (22).

A zatem efekt cieplny reakcji izobaryczno-izotermicznej jest równy przyrostowi entalpii reagentów - równanie (23).

$\mathrm{Z}$ równań opisujących efekt cieplny reakcji wynika, że przy zwiększeniu liczby kilomoli reagentów $\left(\sum \mathrm{v}>0\right)$ efekt cieplny reakcji izobaryczno-izotermicznej jest większy od efektu cieplnego reakcji izochoryczno-izotermicznej $\left(\mathrm{Q}_{\mathrm{p}, \mathrm{T}}>\mathrm{Q}_{\mathrm{V}, \mathrm{T}}\right)$. Jeżeli liczba kilomoli reagentów nie ulegnie zmianie $\left(\sum \mathrm{v}=0\right)$ to efekty cieplne obu reakcji są sobie równe $\left(\mathrm{Q}_{\mathrm{p}, \mathrm{T}}=\mathrm{Q}_{\mathrm{V}, \mathrm{T}}\right)$. A w przypadku zmniejszenia liczby kilomoli $\left(\sum \mathrm{v}<0\right)$ efekt cieplny reakcji izobaryczno-izotermicznej jest mniejszy od efektu cieplnego reakcji izochorycznoizotermicznej $\left(\mathrm{Q}_{\mathrm{p}, \mathrm{T}}<\mathrm{Q}_{\mathrm{V}, \mathrm{T}}\right)$.

Przy teoretycznym rozpatrywaniu obiegów silników spalinowych zakłada się izochoryczny przebieg spalania w silnikach o zapłonie iskrowym oraz częściowo izochoryczny, a częściowo izobaryczny przebieg procesu spalania w silnikach o zapłonie samoczynnym. Zastosowanie konwencjonalnych paliw, w postaci benzyny i oleju napędowego (dla $\lambda \geq 1$ ) powoduje wzrost liczby kilomoli reagentów $w$ komorze spalania, a zatem efekt cieplny reakcji izobaryczno-izotermicznej jest większy od efektu cieplnego reakcji izochoryczno-izotermicznej. Sugerowałoby to, że zmiana objętości reagentów ma większy wpływ na efekt energetyczny procesu spalania w silnikach o zapłonie samoczynnym.

Ponieważ jednak w rzeczywistości proces spalania w obu typach silników jest bliższy obiegowi teoretycznemu silnika o zapłonie samoczynnym oddziaływanie zjawiska kontrakcji na efekt cieplny poszczególnych reakcji w rozważaniach teoretycznych należy ograniczyć do rodzaju paliwa.

I tak dla rozpatrywanych paliw ciekłych przy mieszankach stechiometrycznej (rys. 2) i ubogich następuje zwiększenie liczby kilomoli składników gazowych w związku, z czym efekt cieplny reakcji izobaryczno-izotermicznej 
engine and partly isochoric and partly isobaric in diesel engines. The application of conventional fuels - gasoline and diesel fuel (for $\lambda \geq 1$ ) results in an increase in the kmole number of the reagents in the combustion chamber, hence the thermal effect of the isobaric-isothermal reaction is greater than the thermal effect of the isochoric-isothermal reaction. This would suggest that the change in the volume of the reagents has a greater influence on the energetic effect of the combustion process in diesel engines.

Since, in reality, the combustion process in both engine types is closer to the theoretical cycle of a diesel engine, the influence of the phenomenon of contraction on the thermal effect of the individual reactions in theoretical considerations needs to be confined to type of fuel.

For the liquid fuels under analysis with stoichiometric and lean mixtures (Fig. 2) an increase in the kmole number of the gaseous components takes place resulting in the thermal effect of the isobaric-isothermal is greater than the thermal effect of the isochoric-isothermal reaction. With rich mixtures the kmole number is reduced, hence the thermal effect of the isochoric-isothermal will prevail.

When analyzing gaseous fuels such convergence of the result of volume contraction on the energetic effect of combustion is no longer possible. A mixture of propane and butane shows an increase in the volume of the reagents in the whole range of the excess air coefficient. Methane is characterized by a lack of change in the kmole number forming a stoichiometric and lean mixtures with air, hence the thermal effect of both reactions is the same while in the rich mixture the number of kmoles increases, which results in a prevalence of the isobaric-isothermal reaction (in terms of the thermal effect of combustion). The combustion of hydrogen, irrespective of the mixture composition results in a reduction of the volume of the combustion products against the substrates i.e. the thermal effect will mainly result from the isochoricisothermal reaction. Such varied course of the change in the volume of the reagents for the combustion of gaseous fuels is a result of different chemical composition

\section{Conclusions}

Combustion engines are a fundamental source of propulsion for vehicles whose application is extremely wide and their number results in a significant influence on the quality of air. That is why efforts are made to reduce the exhaust emissions to the atmosphere, which also entails ensuring the greatest possible efficiency of use of the energy contained in the fuel. Since fossil fuels are on the verge of depletion, alternative fuels are sought after and that also includes vegetable fuels. jest większy od efektu cieplnego reakcji izochoryczno-izotermicznej. Przy mieszankach bogatych natomiast liczba kilomoli reagentów ulega zmniejszeniu, więc efekt cieplny reakcji izochoryczno-izotermicznej będzie przeważający.

Analizując paliwa gazowe nie można już wykazać takiej zgodności rezultatów zjawiska kontrakcji na efekt energetyczny procesu spalania. Mieszanina propanu z butanem wykazuje wzrost objętości reagentów w całym zakresie współczynnika nadmiaru powietrza. Metan charakteryzuje się brakiem zmiany liczby kilomoli tworząc z powietrzem mieszanki stechiometryczną i ubogie, a więc efekt cieplny obu reakcji jest taki sam, natomiast przy mieszance bogatej następuje wzrost liczby kilomoli, co skutkuje przewagą reakcji izobaryczno-izotermicznej na efekt cieplny spalania. Spalanie wodoru, bez względu na skład mieszanki powoduje zmniejszenie objętości produktów spalania w stosunku do substratów, czyli efekt cieplny będzie głównie wynikał z reakcji izochoryczno-izotermicznej. Tak różny przebieg

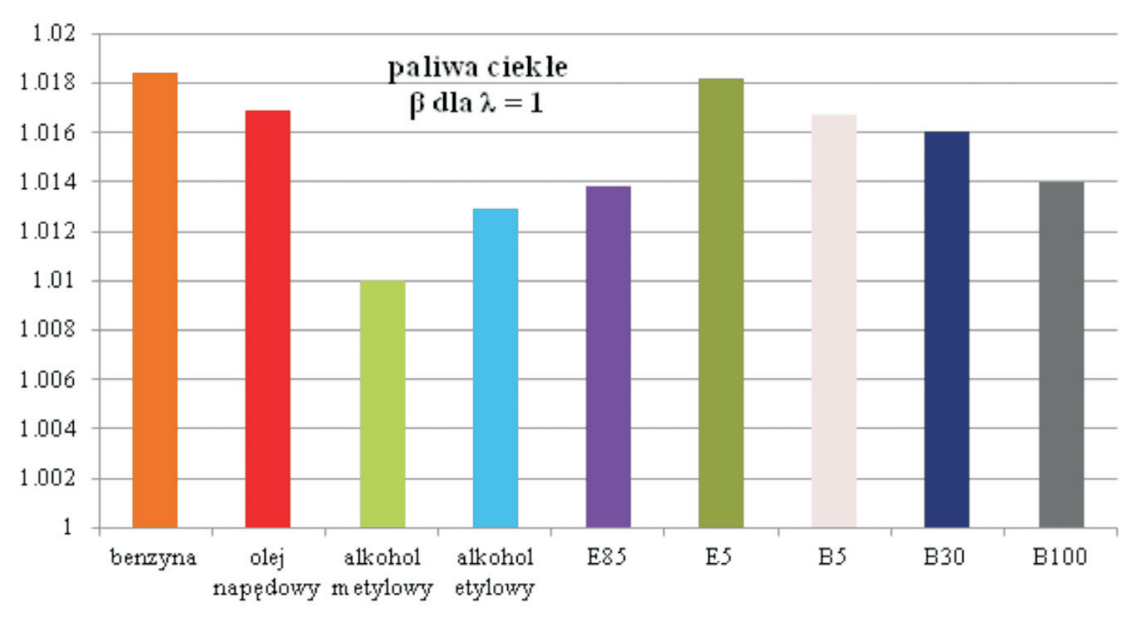

Fig. 2. The coefficient of change of the kmole number for liquid fuels at a stoichiometric mixture composition

Rys. 2. Współczynnik zmiany liczby kilomoli dla paliw ciekłych przy stechiometrycznym składzie mieszanki palnej

zmiany objętości reagentów w przypadku spalania paliw gazowych wynika ze znacznego zróżnicowania ich składu chemicznego.

\section{Wnioski}

Silniki spalinowe stanowią podstawowe źródło napędu pojazdów, których zastosowanie jest bardzo szerokie, a liczebność powoduje znaczący wpływ na jakość powietrza. Dlatego podejmuje się wszelkie starania, aby ograniczyć emisję szkodliwych składników spalin do atmosfery, co również wiąże się z koniecznością jak największej sprawności wykorzystania energii zawartej w paliwie. A ponieważ powszechnie stosowane paliwa kopalne wyczerpują się, szuka się alternatywnych paliw, także pochodzenia roślinnego.

Spalanie paliwa w komorze spalania przeprowadza się przy składzie mieszanki stechiometrycznym lub ubogim, a przeważająca część użytkowanych pojazdów posiada silniki zasilane paliwami ciekłymi. Z punktu widzenia zjawiska 
The combustion of fuels in a combustion chamber is realized with a stoichiometric or lean mixture composition and the majority of the vehicles in use are fitted with engine fueled with liquid fuels. From the point of view of chemical contraction this is advantageous as its influence on the energetic effect of the processes of combustion in these conditions is the greatest, which allows an obtainment of greater values of pressure and temperature, thus a greater thermal effect of the reaction. Analyzing the coefficient of change of the kmole number for the individual liquid fuels (Fig. 2) we can observe that in the case of fossil fuels the effect of contraction is the greatest.

The influence of the gaseous fuel on volume contraction varies widely, which results from the chemical composition of the individual fuels. A mixture of propane and butane is higher order gaseous hydrocarbons of the carbon and hydrogen share in the molecules close to that of liquid fuels, thus the change in the kmole number is similar to liquid fuels. Methane, a simple hydrocarbon has no contraction at all with stoichiometric and lean mixtures. Pure hydrogen, used as fuel that does not contain carbon has negative contraction. kontrakcji chemicznej jest to korzystne, gdyż jej wpływ na efekt energetyczny przemian zachodzących podczas procesu spalania w tych warunkach jest największy, co pozwala uzyskać większe wartości ciśnienia i temperatury, a zatem większy efekt cieplny reakcji. Jednocześnie analizując współczynnik zmiany liczby kilomoli dla poszczególnych paliw ciekłych (rys. 2) można stwierdzić, iż w przypadku paliw kopalnych oddziaływanie kontrakcji jest największe.

Wpływ paliwa gazowego na zjawisko kontrakcji jest znacznie zróżnicowany, co wynika ze składu chemicznego poszczególnych paliw. Mieszanina propanu z butanem to węglowodory gazowe wyższych rzędów, o udziałach węgla i wodoru w cząsteczkach zbliżonych do udziałów tych pierwiastków w paliwach ciekłych, w związku, z czym zmiana liczby kilomoli przebiega podobnie jak dla paliw ciekłych. Metan, będący prostym węglowodorem wykazuje zerową kontrakcję przy mieszankach stechiometrycznej i ubogich. Natomiast czysty wodór stosowany jako paliwo, które nie zawiera w swym składzie węgla wykazuje ujemną kontrakcję.

\section{Nomenclature/Skróty i oznaczenia}

$\mathrm{M}_{\mathrm{c}}$ molar mass of the liquid fuel air mixture/masa molowa mieszanki powietrza z paliwem ciektym

$\mathrm{M}_{\mathrm{g}} \quad$ molar mass of the gaseous fuel - air mixture/masa molowa mieszanki powietrza z paliwem gazowym

$\mathrm{M}_{\mathrm{sp}} \quad$ molar mass of the exhaust gas during combustion of liquid fuel/masa molowa spalin przy spalaniu paliwa ciektego

$\mathrm{M}_{\text {sp g }} \quad$ molar mass of the exhaust gas during combustion of gaseous fuel/masa molowa spalin przy spalaniu paliwa gazowego

$\mathrm{M}_{\mathrm{x}} \quad$ current molar mass of the working medium/biezaca masa molowa czynnika roboczego

$\mathrm{M}_{1} \quad$ molar mass of the working medium before combustion/ masa molowa czynnika roboczego przed spalaniem

$\Delta \mathrm{M}-\quad$ change in the kmole number of the reagents/zmiana liczby kilomoli reagentów

$\mathrm{L}_{\mathrm{t}} \quad$ theoretical air demand for combustion/teoretyczne zapotrzebowanie powietrza do spalania pressure/ciśnienie

$\mathrm{V} \quad$ volume/objętość

\section{Bibliography/Literatura}

[1] Dowkontt J.: Teoria silników cieplnych. WkiŁ, Warszawa 1973.

[2] Kowalewicz A.: Podstawy procesów spalania. WNT, Warszawa 2000.

[3] Niewiarowski K.: Tłokowe silniki spalinowe. WkiŁ, Warszawa 1983.

[4] Szewczyk W., Wojciechowski J.: Wykłady z termodynamiki z przykładami zadań. Wydawnictwa AGH, Kraków 2007.

[5] Wiśniewski S.: Obciążenia cieplne silników tłokowych. WKiも, Warszawa 1972.

[6] Wiśniewski S.: Termodynamika techniczna. WNT, Warszawa 1980.

\section{temperature/temperatura}

universal gas constant/uniwersalna stała gazowa

$\mathrm{Q}_{\mathrm{p} . \mathrm{T}} \quad$ heat of the isobaric-isothermal reaction/ciepło reakcji izobaryczno-izotermicznej

$\mathrm{Q}_{\mathrm{V} . \mathrm{T}} \quad$ heat of the isochoric-isothermal reaction/ciepło reakcji izochoryczno-izotermicznej

internal energy/energia wewnętrzna

$\lambda \quad$ excess air coefficient/współczynnik nadmiaru powietrza

$\beta_{\mathrm{t}} \quad$ theoretical coefficient of contraction/teoretyczny wspótczynnik kontrakcji

$\beta \quad$ coefficient of contraction/wspótczynnik kontrakcji

$\beta_{\mathrm{x}} \quad$ current coefficient of contraction/bieżacy współczynnik kontrakcji

$\gamma \quad$ coefficient of charge contamination/współczynnik zanieczyszczenia ładunku

$\mathrm{X} \quad$ share of the burned fuel/udziat spalonego paliwa

$\Sigma \mathrm{V} \quad$ sum of the kmoles of the reagents/suma kilomoli reagentów
Barbara Worsztynowicz, DEng. - doctor at AGH University of Science and Technology in the Faculty of Mechanical Engineering and Robotics. Dr inż. Barbara Worsztynowicz - adiunkt w AGH Akademii Górniczo-Hutniczej w Krakowie na Wydziale Inżynierii Mechanicznej i Robotyki. e-mail:worsztyn@agh.edu.pl

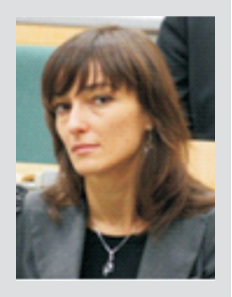

